\title{
PENGARUH PEMBELAJARAN MENGGUNAKAN STRATEGI QUANTUM TEACHING DAN MOTIVASI TERHADAP HASIL BELAJAR IPA PESERTA DIDIK KELAS V GUGUS I KECAMATAN PADANG BARAT KOTA PADANG
}

\author{
Lenny Zaroha ${ }^{1}$, Firman $^{2}$, Desyandri ${ }^{2}$ \\ ${ }^{1}$ Mahasiswa Pendidikan Dasar, Pascasarjana Universitas Negeri Padang \\ ${ }^{2}$ Staff Pengajar Program Studi Pendidikan Dasar, Pacsasarjana Universitas Negeri Padang \\ Lennyzaroha@yahoo.co.id
}

\begin{abstract}
This research is conducted based on low learning outcomes of students especially on science subjects. The low learning outcomes of student,can not be separated from the learning process that lasted for this. One effort to overcome these problems is by usingthe Quantum Teaching strategy in learning. The purpose of this study is to reveal the influence of Quantum Teaching strategy and students motivation to increase the learning outcomes of science. This research used Quasi Experiment with $2 \times 2$ factorial design. The population in this study were students of class $V$ at Gugus 1 Kecamatan Padang Barat Kota Padang. The sample of this research was chosen by simple random sampling technique. Research data obtained from the results of test and questionnaire about students motivation. Data analysis was done by using t test technique.The results showed that the science outcomes of students who were taught with Quantum Teaching strategies were better than the students who were taught by using conventional strategy. Learning outcomes of students with high motivation who were taught with Quantum Teaching strategies are better than highly motivated learners taught by conventional strategy. The same thing shown that low-motivated learners who taught with Quantum Teaching strategies are better than low-motivated learners taught by conventional learning strategy.
\end{abstract}

Keywords: Quantum Teaching Learning Strategy, Conventional Approach, Motivation, Learning Outcomes of Science.

\section{PENDAHULUAN}

Pendidikan merupakan hal terpenting dalam kehidupan seseorang. Melalui pendidikan, seseorang dapat dipandang terhormat, memiliki karir yang baik serta dapat bertingkah sesuai norma-norma yang berlaku. Pendidikan adalah usaha sadar dan terencana secara etis, sistematis dan kreatif dimana peserta didik mengembangkan potensi diri, kecerdasan, pengendalian diri dan keterampilan untuk membuat dirinya berguna di masyarakat.

Perhatian di bidang peningkatan mutu pendidikan dilakukan pada setiap jenjang. Salah satu level atau jenjang pendidikan yang menjadi fokus pemikiran dalam hal peningkatan mutu kurikulum adalah jenjang pendidikan Sekolah Dasar (SD) (Majid, 2014:64).

Salah satu kurikulum yang saat ini masih dipakai dan digunakan dalam proses pembelajaran di seko- 
lah adalah Kurikulum Tingkat Satuan Pendidikan (KTSP). KTSP merupakan kurikulum yang dikembangkan oleh sekolah dan komite dengan berpedoman pada standar kompetensi lulusan dan standar isi serta panduan penyusunan kurikulum yang dibuat oleh Badan Standar Nasional Pendidikan (BSNP) (Depdiknas, 2006:6). Artinya komite sekolah dan seluruh pihak yang berwenang baik sebagai praktisi atau pemerhati pendidikan berhak mengembangkan kurikulum sesuai dengan karakteristik kedaerahan masing-masing. Namun, perlu diperjelas bahwa pengembangan tersebut perlu mengacu pada beberapa prinsip-prinsip pengembangan kurikulum.

Pelaksanaan yang mencakup seluruh kompetensi mata pelajaran, bersifat perbaikan, pengayaan, dan percepatan sesuai dengan potensi dan tahapan perkembangan, menggunakan multistrategi dan multimedia, serta mendayagunakan potensi alam, sosial, dan budaya serta kekayaan daerah juga merupakan prinsip pelaksanaan KTSP disemua jenjang sekolah.

Peningkatan kualitas pembelajaran yang dilakukan baik melalui reformasi pendidikan yang telah dilakukan belum sepenuhnya mendapatkan hasil yang maksimal. Keberhasilan proses kegiatan belajar mengajar pada pembelajaran IPA dapat juga diukur dari keberhasilan peserta didik yang mengikuti kegiatan pembelajaran tersebut, yang meliputi tingkat pemahaman, penguasaan materi, serta prestasi belajar peserta didik. Semakin tinggi pemahaman dan pemguasaan materi serta prestasi belajar peserta didik semakin tinggi pula tingkat keberhasilan.

Dalam pembelajaran IPA, ada banyak kemungkinan pendekatan yang digunakan seperti pembelajaran konvensional dan model pembelajaran Quantum Teaching. Pembelajaran dengan pendekatan konvensional dipandang kurang efektif, karena pembelajarannya hanya berpusat pada guru dan peserta didik tidak diberi kesempatan untuk aktif mengembangkan berbagai kemampuan Science Procces Skill atau kemampuan ilmiah dasar siswa. Sedangkan pembelajaran IPA haruslah mengaktifkan proses pembelajaran dan anak dijadikan sebagai subjek pembelajaran. Beberapa alasan siswa mengalami kesulitan dalam mempelajari IPA diantaranya ke-mampuan siswa terbatas dalam merekam 
informasi, menghafal kon-sep materi yang dipelajari, dan kesulitan apabila dihadapkan dengan soal cerita. Siswa sebatas bisa menyelesaikan soal yang dicontohkan guru dalam pembelajaran, sehingga kemampuan komunikasi belum berkembang.

Berdasarkan studi pendahuluan melalui observasi serta beberapa analisis dokumen hasil belajar siswa yang penulis lakukan di SDN 22 Ujung Gurun Padang, pada tanggal 20 Mei 2016 diperoleh beberapa permasalahan IPA. Permasalahan yang penulis temukan berasal dari dua pokok, yakni permasalahan yang ditimbulkan oleh guru, dan permasalahan yang ditimbul dari siswa. permasalahan yang timbul dari guru adalah guru kurang variatif dalam menyajikan materi pembelajaran, pembelajaran masih berpusat pada buku serta berjalan satu arah saja (teacher centered), susunan kursi yang jarang berubah, kurang memberi pengalaman belajar bagi siswa seperti kegiatan pengamatan, pengendapan pengetahuan melalui kata kunci atau rumus unik, serta belum menggunakan media konkrit bagi peserta didik. Akibat dari permasalahan tersebut, maka muncul pula permasalahan baru yang ditimbulkan oleh peserta didik sebagai berikut, masih adanya peserta didik yang suka keluar kelas sehingga secara tidak langsung mengganggu proses pembelajaran, kurang aktifnya peserta didik dalam proses pembelajaran dimana disini anak lebih cenderung banyak diam. Tidak adanya keinginan untuk bertanya, malu mengeluarkan pendapat atau ide, serta kurang kosentrasi dalam belajar. Selain data - data yang yang dijelaskan di atas, ada beberapa orang siswa yang kurang termotivasi untuk mengikuti setiap pembelajaran, cenderung meletakkan kepalanya di atas meja, mengganggu teman di saat belajar, serta banyak termenung ketika guru bertanya.

Permasalahan yang ditemukan di atas, membutuhkan upaya pemecahan sebagai jalan keluar dari permasalahan tersebut. Salah satu solusi adalah penggunaan strategi pembelajaran yang tepat, yaitu strategi pembelajaran yang mampu membuat seluruh siswa terlibat dalam suasana pembelajaran. Salah satu alternatif yang dapat dilakukan oleh seorang guna lebih mengaktifkan dan memunculkan motivasi belajar siswa di kelas yaitu dengan menggunakan strategi pembelajaran Quantum Teaching, yaitu sebuah strategi 
pembelajaran yang memadukan setiap komponen pembelajaran dengan emosional siswa sehingga adanya keterkaitan antara guru dan kondisi emosional siswa yang dapat membuat pembelajaran lebih berarti dan permanen (Goleman 1995 dalam DePorter 2007: 22).

Selain itu dalam strategi pembelajaran Quantum Teaching segala aspek yang berkaitan dengan pembelajaran dituntut agar segalanya berbicara dan bertujuan ini artinya segalanya dari lingkungan kelas hingga bahasa tubuh seorang guru dan murid semuanya mengirim pesan tentang belajar sehingga pesan dan informasi dapat diterima dengan baik oleh setiap peserta didik. Disinilah letak keunikan strategi pembelajaran Quantum Teaching, yaitu mengubah bermacam-macam interaksi yang ada di dalam dan di sekitar momen belajar menjadi sesuatu hal yang bermanfaat bagi mereka sendiri dan orang lain.

Dengan kata lain, keunggulan yang dimiliki strategi pembelajaran ini lebih kepada aspek keceriaan, komunikasi yang fleksibel, tantangan berupa teka-teki atau permainan yang membuat siswa lebih antusias dalam mengikuti pembelajaran, serta penggunaan bermacam-macam alat peraga yang menarik yang mampu memberikan pengalaman belajar yang aktif dan menyenangkan. Untuk lebih memastikan hasil dan pemfokusan peserta didik dalam hal menemukan dan menerima pesan pembelajaran dari guru, penggunaan yel-yel dan ice breaking sebagai salah satu bantuan yang dapat disatukan dalam pembelajaran di kelas menjadikan keunggulan tersendiri, mengingat bahwa Quantum Teaching merpakan salah satu strategi pembelajaran yang sangat memanfaatkan peran ice breaking sebagai alat penyampai pesan pembelajaran yang diyakini dapat melibatkan secara utuh pemfokusan, ketertarikan, dan keunikan tersendiri bagi peserta didik dalam proses pembelajaran di kelas.

Berdasarkan fenomena tersebut di atas, menarik dikaji lebih lanjut dalam penelitian ini bagaimana "Pengaruh Pembelajaran Menggunakan Strategi pembelajaran Quantum Teaching dan Motivasi terhadap Hasil Belajar IPA Peserta didik Kelas V Gugus 1 Kecamatan Padang Barat Kota Padang”.

\section{METODE PENELITIAN}

Penelitian ini berjenis quasi eksperimen yang bertujuan untuk mengungkapkan hubungan sebab 
akibat dengan cara melibatkan kelompok kontrol di samping kelompok eksperimen (Ibnu dkk, 2003). Rancangan penelitian ini menggunakan pola factorial design $2 \times 2$.

Penelitian ini dilaksanakan pada siswa kelas V SDN 22 Ujung Gurun Kota Padang tahun pelajaran 2016/2017. Subjek penelitian berjumlah 60 siswa yang terbagi atas 30 siswa kelas eksperimen dan 30 siswa kelas kontrol. Instrumen yang digunakan ada dua yaitu angket motivasi dan tes hasil belajar IPA. Instrumen yang berupa angket untuk memperoleh data tentang tingkatan motivasi belajar siswa dan instrumen berupa tes hasil belajar siswa digunakan untuk memperoleh data tentang hasil belajar koqnitif.

Data dalam penelitian ini dikumpulkan melalui penyebaran angket motivasi belajar dan tes hasil belajar IPA pada kelas eksperimen dan kelas kontrol. Tes hasil belajar IPA mencakup sekumpulan pengetahuan IPA yang terdiri dari 30 butir soal objektif, dan angket motivasi belajar berjumlah 45 butir pernyataan.

Teknik analisis data yang digunakan adalah dengan uji t-tes dan analisis varian dua arah. Sebelum dilakukan uji t-tes dan analisis varians dua arah untuk menguji hipotesis, terlebih dahulu dilakukan uji normalitas dan uji homogenitas dengan bantuan SPSS 17.0. Apabila data berdistribusi normal dan varian antar kelompok homogen, maka uji hipotesis dapat diteruskan. Sebagai variabel bebas adalah strategi pembelajaran Quantum Teaching variabel moderator dalam penelitian ini adalah motivasi belajar, dan sebagai variabel terikat adalah hasil belajar IPA.

\section{HASIL DAN PEMBAHASAN}

\section{A. Hasil Penelitian}

Pelaksanaan penelitian ini dilakukan selama tujuh kali pertemuan. Materi yang diajarkan adalah cahaya dan sifat-sifatnya. Pada proses pembelajaran kedua kelas memperoleh perlakuan yang berbeda. Kelas eksperimen dengan menggunakan strategi pembelajaran Quantum Teaching sedangkan kelas kontrol dengan pembelajaran konvensional. Oleh karena itu, perubahan akan terjadi setelah perlakuan diberikan. Pada akhir pembelajaran kedua kelas diberikan tes akhir yang sama untuk mengetahui kelas mana yang memiliki hasil belajar yang lebih 
tinggi. Dalam hal ini hasil belajarnya berupa hasil belajar IPA siswa.

Berdasarkan hasil analisis data pada skor hasil belajar IPA siswa kelas V SDN 22 Ujung Gurun yang diteliti, menunjukkan bahwa siswa yang diajar dengan model strategi pembelajaran Quantum Teaching lebih baik secara keseluruhan, baik kelompok siswa yang memiliki motivasi belajar yang tinggi maupun kelompok siswa yang memiliki motivasi belajar yang rendah. Secara emperis ini terbukti dari hasil uji hipotesis yang telah dilakukan.

Berdasarkan hasil uji hipotesis tersebut dilakukan pembahasan. Dalam pembahasan ini, diuraikan empat pokok kajian yang dikaitkan dengan acuan teori yang relevan, yaitu: (a) hasil belajar IPA siswa yang diajar dengan strategi pembelajaran Quantum Teaching dan pembelajaran konvensional, (b) hasil belajar IPA siswa yang memiliki motivasi tinggi yang diajar dengan strategi pembelajaran Quantum Teaching dan pendekatan konven-sional, dan (c) hasil belajar IPA siswa yang memiliki motivasi rendah yang diajar dengan strategi pembelajaran Quantum Teaching dan pendekatan konvensional.
Penelitian ini menggunakan kelas VB SDN 22 Ujung Gurun Kota Padang sebagai kelas kontrol dengan memperoleh pembelajaran secara konvensional dan kelas VA SDN 22 Ujung Gurun sebagai kelas eksperimen dengan strategi pembelajaran Quantum Teaching. Jumlah subjek pada kelas kontrol sebanyak 30 siswa dan pada kelas ekperimen sebanyak 30 siswa. Hasil penelitian yang berupa rerata hasil tes hasil belajar IPA pada masing-masing kelompok disajikan pada tabel 1 , sebagaimana berikut.

Tabel 1. Perbandingan Rerata Hasil Tes Hasil belajar IPASiswa

\begin{tabular}{|c|c|c|c|}
\hline $\begin{array}{c}\text { Kelas } \\
\text { Perla kuan }\end{array}$ & $\begin{array}{c}\text { Motivasi } \\
\text { Belajar }\end{array}$ & Skor rerata & $\mathbf{N}$ \\
\hline \multicolumn{4}{|c|}{ Kognitif } \\
\hline \multirow{3}{*}{ Quantum Teaching } & Rendah & 70,41 & 12 \\
\hline & Tinggi & 77,61 & 18 \\
\hline & Total & 74,63 & 30 \\
\hline \multirow{3}{*}{ Konvensional } & Rendah & 55,94 & 18 \\
\hline & Tinggi & 60,58 & 12 \\
\hline & Total & 59,13 & 30 \\
\hline \multicolumn{4}{|c|}{ Afektif } \\
\hline \multirow{3}{*}{ Quantum Teaching } & Rendah & 13,25 & 12 \\
\hline & Tinggi & 13,67 & 18 \\
\hline & Total & 13,53 & 30 \\
\hline \multirow{3}{*}{ Konvensional } & Rendah & 11,83 & 18 \\
\hline & Tinggi & 12,42 & 12 \\
\hline & Total & 12,07 & 30 \\
\hline \multicolumn{4}{|c|}{ Psikomotor } \\
\hline \multirow{3}{*}{ Quantum Teaching } & Rendah & 9,08 & 12 \\
\hline & Tinggi & 9,28 & 18 \\
\hline & Total & 8,77 & 30 \\
\hline \multirow{3}{*}{ Konvensional } & Rendah & 7,17 & 18 \\
\hline & Tinggi & 7,00 & 12 \\
\hline & Total & 7,00 & 30 \\
\hline
\end{tabular}

Tabel di atas mendeskripsikan bahwa Rata-rata hasil tes hasil belajar IPA siswa baik pada ranah kognitif, afektif, dan psikomotor siswa yang 
diajar dengan menggunakan strategi pembelajaran Quantum Teaching lebih tinggi daripada rata-rata hasil belajar IPA (kognitif, afektif, dan psikomotor) siswa yang diajar dengan menggunakan pendekatan konvensional. Hal tersebut diperkuat melalui hasil uji hipotesis menggu nakan uji t-tes dan analisis varians dua arah dengan taraf kepercayaan $5 \%(\alpha=0,005)$, terhadap data hasil penelitian disajikan pada table 2 berikut.

\section{Tabel 2. Hasil Uji Hipotesis}

\begin{tabular}{|c|c|c|c|}
\hline Kelas Sampel & $\mathbf{N}$ & Rata-rata & Sign. \\
\hline \multicolumn{4}{|l|}{ HIPOTESIS 1} \\
\hline \multicolumn{4}{|c|}{ KOGNITIF } \\
\hline Eksperimen & 30 & 74,63 & \multirow{2}{*}{0,000} \\
\hline Kontrol & 30 & 59,13 & \\
\hline \multicolumn{4}{|c|}{ AFEKTIF } \\
\hline Eksperimen & 30 & 13,37 & \multirow{2}{*}{0,0065} \\
\hline Kontrol & 30 & 12,07 & \\
\hline \multicolumn{4}{|c|}{ PSIKOMOTOR } \\
\hline Eksperimen & 30 & 8,47 & \multirow{2}{*}{0,00015} \\
\hline Kontrol & 30 & 7,47 & \\
\hline \multicolumn{4}{|l|}{ HIPOTESIS II } \\
\hline \multicolumn{4}{|c|}{ KOGNITIF } \\
\hline Eksperimen & 18 & 77,61 & \multirow{2}{*}{0,0035} \\
\hline Kontrol & 12 & 60,58 & \\
\hline \multicolumn{4}{|c|}{ AFEKTIF } \\
\hline Eksperimen & 18 & 13,39 & \multirow{2}{*}{0,0042} \\
\hline Kontrol & 12 & 12,42 & \\
\hline \multicolumn{4}{|c|}{ PSIKOMOTOR } \\
\hline Eksperimen & 18 & 8,89 & \multirow{2}{*}{0,0011} \\
\hline Kontrol & 12 & 7,00 & \\
\hline \multicolumn{4}{|l|}{ HIPOTESIS III } \\
\hline \multicolumn{4}{|c|}{ KOGNITIF } \\
\hline Eksperimen & 12 & 70,42 & \multirow{2}{*}{0,007} \\
\hline Kontrol & 18 & 55,94 & \\
\hline \multicolumn{4}{|c|}{ AFEKTIF } \\
\hline Eksperimen & 12 & 13,25 & \multirow{2}{*}{0,045} \\
\hline Kontrol & 18 & 11,83 & \\
\hline \multicolumn{4}{|c|}{ PSIKOMOTOR } \\
\hline Eksperimen & 12 & 8,00 & \multirow{2}{*}{0,015} \\
\hline Kontrol & 18 & 7,94 & \\
\hline \multicolumn{4}{|c|}{ Tabel di } \\
\hline bahwa hasil & tes & hasil & jar \\
\hline siswa kelas & eks & erimen & in kel \\
\hline
\end{tabular}

nyata $\alpha=0,05$ berarti tolak $\mathrm{H}_{0}$ dan terima $\mathrm{H}_{1}$, sehingga dapat disimpulkan bahwa hasil belajar IPA baik pada ranah kognitif, afektif, dan psikomotor siswa yang dibelajarkan dengan menggunakan strategi pembelajaran Quantum Teaching lebih tinggi dibandingkan dengan menggunakan pendekatan konvensional.

Hasil hasil belajar IPA (kognitif, afektif, dan psikomotor) siswa kelas eksperimen dan kelas kontrol untuk peserta didik yang memiliki motivasi tinggi mempunyai nilai Sig. $<$ taraf nyata $(\alpha=0,05)$ berarti tolak $\mathrm{H}_{0}$ dan terima $\mathrm{H}_{1}$. Jadi dapat disimpulkan bahwa hasil tes peserta didik yang memiliki motivasi tinggi yang menggunakan strategi pembelajaran Quantum Teaching le-bih tinggi daripada hasil tes peserta didik yang memiliki motivasi yang menggunakan pendekatan konvensional.

Hasil hasil belajar IPA (kognitif, afektif, dan psikomotor) peserta didik kelas eksperimen dan kelas kontrol untuk peserta didik yang memiliki motivasi rendah mempunyai nilai Sig. $<$ taraf nyata $(\alpha=0,05)$ berarti tolak $\mathrm{H}_{0}$ dan terima $\mathrm{H}_{1}$. Jadi dapat disimpulkan bahwa hasil tes peserta didik yang memiliki motivasi 
rendah yang menggunakan strategi pembelajaran Quantum Teaching lebih tinggi daripada hasil tes peserta didik yang memiliki motivasi yang menggunakan pendekatan konvensional.

Berdasarkan hasil perhitungan hipotesis pertama diperoleh pada masing-masing ranah hasil belajar yakni kognitif, afektif, dan psikomotor secara berurutan memiliki nilai sign. $0,000,0,0065,0,00015$. Pada hipotesis kedua diperoleh sign. $0,0035, \quad 0,0042$, dan 0,00011 . Selanjutnya pada hipotesis ketiga diperoleh sign $0,007,0,045$, dan 0,015. Jadi dapat disimpulkan pertama, pada hipotesis pertama hasil belajar IPA (kognitif, afektif, dan psikomotor) siswa yang diajarkan dengan strategi pembelajaran Quantum Teaching lebih baik daripada hasil belajar IPA siswa yang diajarkan dengan pembelajaran konvensional. Kedua, Pada hipotesis kedua hasil belajar IPA (kognitif, afektif, dan psikomotor) siswa yang memiliki motivasi tinggi yang diajarkan dengan strategi pembelajaran Quantum Teaching lebih baik daripada hasil belajar IPA siswa yang memiliki motivasi belajar tinggi yang diajar dengan pendekatan konven- sional. Ketiga, pada hipotesis ketiga hasil belajar IPA (kognitif, afektif, dan psikomotor) siswa yang memiliki motivasi rendah yang diajar dengan strategi pembelajaran Quantum Teaching lebih baik dari-pada hasil belajar IPA siswa yang memiliki motivasi belajar rendah yang diajar dengan pendekatan konvensional.

Berdasarkan hasil penelitian, dapat dilihat bahwa nilai rata-rata hasil belajar IPA dan motivasi belajar siswa pada kelas eksperimen yang menggunakan strategi pembelajaran Quantum Teaching lebih tinggi dibandingkan nilai rata-rata kelas kontrol yang menggunakan pembelajaran konvensional. Hal tersebut dapat terlihat pada tabel 1 dan tabel 2 .

Hal berbeda ditunjukkan pada hasil uji interaksi dengan anova dua arah terkait dengan interaksi antara stratgei yang digunakan dan motivasi yang berpengaruh terhadap hasil belajar. Hal ini terlihat pada tabel 3 berikut.

Tabel 3. Uji Interaksi Anova Dua Arah

\begin{tabular}{|c|c|c|c|c|c|}
\hline $\begin{array}{l}\text { Sumber } \\
\text { Variansi }\end{array}$ & $\begin{array}{l}\text { Sum of } \\
\text { Squares }\end{array}$ & df & $\begin{array}{l}\text { Mean } \\
\text { Square }\end{array}$ & $\mathbf{F}$ & Sig. \\
\hline Kelas & 3572.100 & 1 & 3572.100 & 16.471 & \multirow{4}{*}{0.743} \\
\hline Motivasi & 504.100 & 1 & 504.100 & 2.324 & \\
\hline Kelas * Motivasi & 23.511 & 1 & 23.511 & 0.108 & \\
\hline Total & 280450.000 & 60 & & & \\
\hline
\end{tabular}


Tabel di atas menunjukkan bahwa perhitungan uji Anova Dua Arah pada tabel di atas, diperoleh nilai Sign. Sebesar 0,743. Oleh karena itu, nilai signifikansi lebih besar dari taraf nyata $(\alpha=0,05)$, maka $\mathrm{H}_{0}$ diterima dan $\mathrm{H}_{1}$ di tolak. Artinya, tidak terdapat interaksi antara strategi pembelajaran Quantum Teaching dan motivasi terhadap hasil belajar peserta didik. Dengan tidak adanya interaksi ini menunjukkan bahwa strategi pembelajaran Quantum Teaching mampu meningkatkan hasil belajar peserta didik. Hal ini bermakna siswa dengan motivasi yang tinggi dan rendah dapat meningkatkan hasil belajarnya.

\section{B. Pembahasan}

Penelitian ini telah mengungkapkan bahwa strategi pembelajaran Quantum Teaching memberikan pengaruh yang positif terhadap hasil belajar IPA, baik itu pada ranah kognitif, afektif, serta psikomotor. Penggunaan strategi pembelajaran Quantum Teaching dalam pembelajaran IPA, secara nyata peneliti melihat siswa lebih berani dalam mengungkapkan ide dan lebih berani dalam mengemukakan pendapat, terlihat lebih enjoy dan senantiasa dilalui dengan penuh kegembiraan.
Pelaksanaan strategi pembelajaran Quantum Teaching berhasil mempengaruhi hasil belajar IPA peserta didik. Kenyataannya, hasil belajar IPA peserta didik yang mendapat perlakuan dengan menggunakan strategi pembelajaran Quantum Teaching menunjukkan peningkatan secara signifikan dibandingkan dengan siswa yang tidak mendapat perlakuan. Oleh karena itu, keung-gulan strategi pembelajaran Quantum Teaching dapat ditemui dan bermanfaat dalam proses pembelajaran.

Hal tersebut membuktikan pernyataan sebagaimana yang diungkapkan oleh hasil penelitian SuperCamp terhadap strategi pembelajaran Quantum Teaching yang menyebutkan bahwa Quantum Teaching dapat meningkatkan beberapa hasil dari pada proses pembelajaran sebagai berikut $68 \%$ meningkatkan motivasi belajar siswa, 73\% meningkatkan prestasi belajar siswa, $81 \%$ meningkatkan rasa percaya diri siswa, 98\% melanjutkan penggunaan keterampilan (DePorter, 2000:10). Hal lain juga diungkapkan oleh DePorter terkait dengan keunggulan yang dimiliki oleh strategi pembelajaran Quantum 
Teaching mengemukakan bahwa penggunaan strategi pembelajaran Quantum Teaching memungkinkan banyak siswa untuk lebih dapat maksimal dalam berinteraksi dengan lingkungan sekitar, karena hal ini merupakan cara untuk menggali lebih dalam informasi yang mereka peroleh, sehingga siswa berani dalam mengaktualisasikan dirinya. Jadi, keunggulannya terletak pada seluruh komponen dalam kelas yang memiliki pesan belajar serta cara baru belajar yang lebih menarik dengan mengemukakan hal-hal yang dekat dengan siswa. Sehingga, siswa merasa pembelajaran ini menarik dan merupakan hal konkrit karena berhubungan dengan kegiatan seharihari.

Pada strategi pembelajaran Quantum Teaching setiap siswa mempunyai tanggung jawab untuk menamai dan mendemonstrasikan seluruh kegiatan yang mereka lalui, baik itu percobaan ataupun diskusi. Kegiatan "namai" secara nyata membimbing siswa dalam mengingat kata kunci pelajaraan, sehingga siswa dengan mudah mengingat ketika hal yang telah dipelajari masuk dalam soal-soal ataupun pertanyaan yang diberikan oleh guru. Selain itu, kegiatan pengulangan juga memiliki peran tersendiri, dengan mengulang dan menginformasikan secara berkeliling, secara tidak langsung memberikan pemahaman kepada siswa itu sendiri dan siswa lain. Diakhir pembelajaran, kegiatan merayakan merupakan hal yang menarik bagi siswa. hal ini karena, kerja mereka diakui dan diapresiasi oleh guru, sehingga mereka terus bersemangat dalam mengikuti pelajaran. Dari uraian tersebut dimaknai bahwa strategi pembelajaran Quantum Teaching menempatkan siswa sebagai subjek belajar yang menempatkan siswa sebagai penerima dan pemberi informasi secara aktif.

Berbeda dengan strategi pembelajaran Quantum Teaching, pendekatan konvensional yang digunakan pada kelas kontrol menempatkan siswa pada objek belajar yang berperan sebagai penerima informasi secara pasif. Pada umumnya, penyampaian pembelajaran dilakukan dengan menggunakan metode ceramah, tanya jawab, dan penugasan. Guru selalu mendominasi kegiatan pembelajaran, sehingga sangat sedikit siswa mendapat kesempatan untuk meng-eksplor diri 
mereka, siswa lebih banyak mendapatkan dan menerima informasi dari guru. Hal ini sesuai dengan pendapat Djaafar (2001:13) yang menyatakan bahwa metode belajar konvensional merupakan metode yang berorientasi pada guru, hampir seluruh kegiatan dikendalikan oleh guru. Tidak ada kesempatan bagu siswa untuk ikut memberikan kontribusi terhadap pengetahuan, keterampilan, dan sikap dalam proses pembelajaran. Siswa yang diajar dengan pendekatan konvensional cenderung tidak percaya diri dan malu untuk mengungkapkan pengetahuan yang mereka miliki, siswa hanya menunggu informasi dari guru dan tidak terbiasa dalam memberikan dan menemukan sendiri jawaban dari permasalahan yang diberikan guru.

Pada pembelajaran konvensional, siswa tidak mempunyai kemampuan untuk menemukan kata kunci dari setiap pertemuan yang pembelajaran. pendekatan konvensional lebih banyak dan cenderung menghafal dari pada menemukan sendiri. Sehingga permasalahan dalam pertanyaan yang diberikan guru kurang mendapat jawaban yang tepat. Siswa kelas kontrol cenderung hanya bisa menghafal apa yang diberikan oleh guru dan buku sumber yang ada, sehingga ketika diberi soal yang sedikit berbeda mereka cenderung tidak bisa dan salah dalam menjawab. Berdasarkan penjelasan tersebut, dapat dikatakan bahwa karakteristik antara strategi pembelajaran Quantum Teaching dan pendekatan konvensional merupakan kunci yang menyebabkan hasil belajar IPA dan motivasi belajar siswa yang diajarkan dengan strategi pembelajaran Quantum Teaching lebih tinggi dari pada siswa yang diajar dengan pendekatan konvensional.

Hal tersebut dapat dilihat pada saat penelitian berlangsung, siswa yang diajarkan dengan model konvensional menunjukkan sikap pasif. Siswa hanya menjelaskan penjelasan guru, mencatat, serta menjawab pertanyaan jika guru bertanya. Tidak memiliki inisiatif untuk bertanya ataupun berinteraksi dengan teman sebangku untuk membahas hal-hal yang berhubungan dengan materi yang sedang dipelajari. Kemudian me-ngerjakan latihan yang ditugaskan guru. Hal tersebut dikarenakan peran guru yang sangat mendominasi dalam pembelajaran, sebagaimana pendapat Nasution 
(1995:209) yang menge-mukakan bahwa peran guru dalam pembelajaran konvensional mengakibatkan siswa kurang berperan aktif dan lebih banyak mendengarkan penjelasan dari guru daripada menemukan sendiri pengetahuan, sikap, dan keterampilan yang dibutuhkan, karena pembelajaran siswa berperan sebagai objek belajar pasif, yang kegiatannya mende-ngarkan uraian guru, belajar sesuai dengan kecepatan guru mengajar dan mengikuti tes mengenai bahan yang dipelajari.

Berdasarkan uraian di atas, dari hasil temuan penelitian dan analisis data dapat disimpulkan bahwa strategi pembelajaran Quantum Teaching memberikan pengaruh terhadap hasil belajar IPA siswa. Hal ini dibuktikan dari perbedaan rerata hasil tes kelas eksperimen yang diajar dengan strategi pembelajaran Quantum Teaching lebih tinggi dibandingkan dengan kelas kontrol yang diajarkan dengan pendekatan konvensional. Namun tidak memberikan interaksi antara strategi pembelajaran Quantum Teaching dan motivasi dalam memperngaruhi hasil belajar peserta didik. Hal ini disebabkan karena keduanya memiliki pengaruh sendiri-sendiri terhadap hasil belajar peserta diidk.

\section{SIMPULAN, IMPLIKASI DAN SARAN}

\section{A. Simpulan}

Berdasarkan kesimpulan yang telah dikemukakan, peneliti mengemukakan beberapa saran sebagai berikut:

1. Hasil belajar IPA siswa yang mengikuti pembelajaran dengan menggunakan strategi pembelajaran Quantum Teaching lebih baik dari pada siswa yang mengikuti pembela-jaran dengan pendekatan konvensional.

2. Hasil belajar IPA siswa yang memiliki motivasi tinggi yang mengikuti pembelajaran dengan strategi pembelajaran Quantum Teaching lebih baik dari pada hasil belajar IPA siswa yang memiliki motivasi tinggi yang mengikuti pembela-jaran dengan pendekatan konvensional.

3. Hasil belajar IPA siswa yang memiliki motivasi rendah yang mengikuti pembalajaran dengan strategi pembelajaran Quantum Teaching lebih baik dari pada siswa yang memiliki motivasi rendah yang diajarkan dengan pendekatan konvensional. 
4. Tidak terdapat interaksi antara strategi pembelajaran Quantum Teaching dan Motivasi Belajar yang berpengaruh terhadap hasil belajar IPA peserta didik (kognitif, afektif, dan psikomotor).

Beberapa poin di atas membuktikan bahwa strategi pembelajaran Quantum Teaching berpengaruh terhadap hasil belajar IPA (kognitif, afektif, dan psikomotor) dan motivasi belajar siswa kelas $\mathrm{V}$ SD Negeri 22 Ujung Gurun Kota Padang tahun pelajaran 2016/2017 pada materi cahaya dan sifatnya.

\section{B. Implikasi}

Implikasi pada penelitian ini dapat diuraikan sebagai berikut.

a. Pemilihan strategi pembelajaran yang tepat dapat berpengaruh terhadap pencapaian hasil belajar siswa. untuk pelajaran IPA, terdapat perbedaan hasil belajar antara pembelajaran yang menggunakan strategi pembela-jaran Quantum Teaching dan pendeka$\tan$ konvensional.

b. Motivasi belajar siswa mempunyai pengaruh terhadap hasil belajar IPA. Siswa dengan motivasi belajar yang tinggi tentunya mempunyai hasil belajar lebih baik dari pada siswa dengan motivasi belajar yang rendah. Diharapkan guru dapat menumbuhkan motivasi belajar pada diri siswa dengan berbagai cara sesuai dengan kemampuan guru dan menarik bagi siswa.

c. Hasil penelitian ini digunakan sebagai bahan bagi kepala sekolah, guna memberikan pelatihan dan pemahaman tentang strategi pembelajaran Quantum Teaching agar dapat diterapkan oleh guruguru dan staff pengajar yang ada di sekolah. Membenahi diri sehubungan dengan pengajaran yang telah dilakukan dan hasil belajar siswa yang telah dicapai dengan memperhatikan model pembelajaran yang tepat dan motivasi belajar siswa untuk meningkatkan hasil belajar IPA siswa, salah satunya adalah strategi pembelajaran Quantum Teaching .

C. Saran

Berdasarkan hasil penelitian ini, ada beberapa hal yang penulis sarankan, antara lain:

1. Sebagai bahan masukan bagi guru kelas V untuk memilih strategi pembelajaran yang tepat dalam mengajar IPA. Salah satunya adalah dengan menggunakan strategi pembelajaran Quantum 
Teaching dalam pembelajaran IPA. Karena dengan strategi pembelajaran Quantum Teaching hasil belajar IPA siswa lebih baik dibandingkan dengan pendekatan yang selama ini sering digunakan yakni pendekatakan konvensional.

2. Kepada peneliti selanjutnya, hendaknya melakukan penelitian yang lebih memfokuskan pada hasil belajar yang mencakup tiga ranah yakni kognitif, afektif, dan psikomotorik, sehingga akan lebih membuktikan pengaruh strategi pembelajaran Quantum Teaching terhadap tiga ranah hasil belajar siswa. Kepada peneliti selanjutnya, juga disarankan untuk memfokuskan pada varibel lain yang turut menentukan keberhasilan belajar siswa seperti kecerdasan, kesiapan, daya ingat, dan lainnya, sehigga hasil penelitian benar-benar membuktikan keunggulan strategi pembelajaran Quantum Teaching

\section{DAFTAR RUJUKAN}

DePorter, B. (2000). Quantum Teaching : Mempraktekkan Quantum Learning di Ruang Kelas. Bandung : Kaifa . 2005. Quantum Teaching : Mempraktekkan Quantum
Learning di Ruang Kelas. Bandung : Kaifa

Keller, J. M. \& Thomas W. K. (1987). An application of the ARCS model of motivational design, dalam Charles $M$. Reigeluth (ed), Instructional theories in action, 289-319. Hillsdale, NJ: Lawrence Erlbaum Associates.

Khamsah, D. L. (2016). Peningkatan Pembelajaran IPA dengan Menggunakan Strategi pembelajaran Quantum Teaching di Kelas VI B SDN 11 Kurao Pagang Kecamatan Nanggalo Kota Padang. Tesis : Universitas Negeri Padang. Tidak dipublikasikan.

Sandra K. A, Ken, A. \& Deborah L. H. (2010). Designing and Teaching the Elementary Science Methods Course. New York And London : Routledge Taylor \& Francis Group. Halaman 25-31

Sarah, M., Andrew W. S, \& Heidi A. S. (2010). Ready, Set, Science : Putting Research to Work in K-8 Science Classrooms. The National Academies Press : National Research Council. Halaman 154-156

Sugiyono. (2009). Metode Penelitian Pendidikan Pendidikan Kuantitatif, Kualitatif, dan $R \& D$. Bandung: Alfabeta. 